\title{
Physicochemical and Bioactive Compound Evaluation of Acerola Genotypes
}

aEmpresa Brasileira de Pesquisa Agropecuária, Centro Nacional de Pesquisa em Mandioca e Fruticultura, CEP 44380000, Cruz das Almas-BA, Brazil

buniversidade Federal Rural de Pernambuco, Departamento de Tecnologia Rural, Rua Dom Manoel de Medeiros, Dois irmãos, CEP 52171-900, Recife -PE, Brazil 'Universidade Federal da Bahia, Instituto de Ciências da Saúde, Departamento de Bioquímica e Biofísica, Avenida Reitor Miguel Calmon, CEP 40231-300, Salvador-BA, Brazil.

*E-mail: eliseth.viana@embrapa.br

Recebido: 12 de Junho de 2020

Aceito: 2 de Março de 2021

Publicado online: 14 de Abril de 2021

\section{Avaliação Físico-Química e de Compostos Bioativos de Frutos de Genótipos de Aceroleira}

Eliseth de Souza Viana, ${ }^{a}$ *(D) Mercia Damasceno Fonseca, ${ }^{b}$ Ronielli Cardoso Reis, ${ }^{a}$ Marcos Vinicius Silva de Andrade, ${ }^{c}$ Rogério Ritzingera

\begin{abstract}
Acerola genotypes should have good agronomic traits and high quality of fruits. This study aimed to evaluate the physicochemical characteristics and content of bioactive compounds of fruits of three genotypes of acerola (CMF07-60-03, CMF07-OKSE-3 and Okinawa). The skin color of the fruit was determined by evaluating the coordinate $\mathrm{L}^{*}$ (lightness) and the variables $\mathrm{C}^{*}$ (color intensity) and $\mathrm{h}^{*}$ (angle of color/hue). The physicochemical and bioactive compounds characterization included the study of moisture, ash, $\mathrm{pH}$, total sugars, soluble solids, titratable acidity, ratio, vitamin $\mathrm{C}$, total carotenoids, total extractable polyphenols, and antioxidant activity through ABTS and DPPH methods. Through ANOVA, no significant difference $(p>0.05)$ w as found a mong genotypes for most of the physicochemical characteristics evaluated; however, the principal component analysis allowed to differentiate them, especially the hybrid CMF07-OKSE-3, which showed higher contents of moisture, vitamin $\mathrm{C}$, total extractable polyphenols, higher antioxidant activity and ratio, standing out from the others.
\end{abstract}

Palavras-chave: Malpighia emarginata Sessé \& Moc. ex DC; genotypes; bioactive compounds; vitamin C.

\section{Introduction}

Acerola (Malpighia emarginata Sessé \& Moc. ex DC) is native to the Caribbean islands, Central America and northern South America. ${ }^{1}$ It was introduced in Pernambuco in 1955, but it started to be cultivated commercially in Brazil in the mid-1980s, mainly in the Northeast, especially in the states of Pernambuco, Paraíba, Bahia and Ceará. ${ }^{2}$ Other states such as Pará and São Paulo also stand out in the production of acerola.

It is important to consider that the sustainability and expansion of the acerola crop depends on the development of genotypes with superior characteristics by the breeding programs. The genotypes must have, in addition to good agronomic characteristics, high fruit quality. In general, acerola breeding programs are guided based on the results of evaluations of the agronomic characteristics of the plant and of the physicochemical characteristics of the fruits. However, the contents of bioactive compounds have also been investigated in the fruits of acerola plant due to the interest of consumers and the pharmaceutical and food industries in nutrients that, in addition to nourishing, bring health benefits.

Antioxidants are substances capable of inhibiting or delaying the oxidation of substrates, which can be classified as enzymatic or non-enzymatic. ${ }^{3,4}$ Among non-enzymatic antioxidants, vitamin $\mathrm{C}$, carotenoids and phenolic compounds stand out. ${ }^{5,6}$ Antioxidant phytonutrients such as vitamin $\mathrm{C}$ and phenolic compounds are able to fight free radicals involved in cell degenerative processes, in addition to helping to strengthen the immune system of animals. ${ }^{3}$

Acerola is known mainly for its high vitamin C content (695 to $4827 \mathrm{mg}^{3} 100 \mathrm{~g} \mathrm{~g}^{-1}$ ), being one of the main natural sources of this vitamin. ${ }^{78}$ In Brazil, the recommended daily intake (RDI) of vitamin C for adults is $45 \mathrm{mg},{ }^{9}$ so the daily consumption of three fruits is sufficient to meet the demands of the body. In addition to vitamin $\mathrm{C}$, acerola has other phytochemicals, many of which are of physiological importance, such as anthocyanins and carotenoids. Several studies have investigated the content of carotenoids and polyphenols in acerola because of their antioxidant properties. ${ }^{8,10}$ Carotenoids are present at concentrations from 0.32 to $40.6 \mathrm{mg} 100$ $\mathrm{g}^{-1}$ of acerola pulp, with $\beta$-carotene standing out with 40 to $60 \%$ of total carotenoids. Among

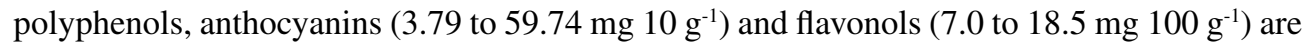
the main components. ${ }^{11}$ 
Considering that the genetic improvement is done by crossing between plants of the same species aiming to combine the best characteristics of different individuals to generate new hybrids, this study aimed to evaluate the fruits of two new acerola hybrids developed by Embrapa and a commercial variety in order to verify whether the hybridization process contributed to generate genotypes with superior physicochemical characteristics, content of bioactive compounds and antioxidant capacity.

\section{Material and Methods}

\subsection{Obtaining fruits and pulp}

Fruits of two new acerola hybrid plants (CMF07-6003 and CMF07-OKSE-3) and the commercial variety Okinawa (control) were evaluated. CMF07-OKSE-3 is a hybrid between Okinawa and Sertaneja varieties from a controlled cross, and CMF07-60-03 originated through open pollination of the genotype CMF060 as the mother plant.

The experiment was installed in an experimental area of Embrapa Cassava and Fruits in Cruz das Almas, BA, Brazil (1240'39" S, 3906'22” $\mathrm{W}$ and $226 \mathrm{~m}$ altitude), using a completely randomized design, at the spacing of $5.0 \mathrm{~m}$ between rows and $2.0 \mathrm{~m}$ between plants in the rows, without irrigation. The region's climate is considered humid tropical with an annual temperature of $24.5^{\circ} \mathrm{C}$, a relative humidity of $80 \%$, and an average annual rainfall of 1,249.7 $\mathrm{mm} .{ }^{12}$ The fruits were harvested 21 days after anthesis, in the mature stage, characterized by the completely red color of the skin. The harvests were carried out in three different seasons (January, April and September) in order to obtain the average annual value of each evaluated characteristic. Approximately one kilogram of fruit from each genotype was harvested, with each harvest representing one experimental replicate. The physicochemical analyses of the fruits were carried out on the same day as the harvest. For the evaluation of bioactive compounds and antioxidant activity, the pulp was frozen at $-18{ }^{\circ} \mathrm{C}$ for later use. The evaluations were carried out in triplicate.

\subsection{Physicochemical assessments}

The color of the fruits was evaluated using the Minolta ${ }^{\circledR}$ colorimeter, model CR400 and the CIELAB color scale, illuminant D65. Two readings were performed on each fruit, in a total of five fruits of each genotype, for the color parameters $\mathrm{L} *, \mathrm{C} *$ and $\mathrm{h} *$, which mean, respectively, lightness, chroma / intensity of color and angle of color/hue.

The fruit pulps were analyzed for $\mathrm{pH}$, soluble solids content, in ${ }^{\circ}$ Brix (SS), titratable acidity, in $\%$ malic acid (TA), moisture ( \%) and ash (\%) according to IAL. ${ }^{13}$ The ratio was calculated dividing the SS content by the titratable acidity. The content of total sugars in $\%$ of glucose was determined by spectrophotometry, ${ }^{14}$ with the acid hydrolysis stage being carried out according to IAL. ${ }^{13}$

\subsection{Obtaining pulp extracts}

To determine the total polyphenol content and antioxidant activity, acerola extracts were prepared as previously described, ${ }^{15}$ with modifications. The extraction was done with $50 \%$ methanol for a period of 20 minutes in an ultrasonic bath, followed by centrifugation at 11,000 $\mathrm{rpm}$ for 15 minutes. The residue was subjected to the second extraction in $70 \%$ acetone, following the same procedure.

\subsection{Determination of bioactive compounds}

Total extractable polyphenols were determined using the Folin-Ciocalteau reagent (1:3) and the standard curve of gallic acid, according to the method described by Singleton et al., ${ }^{16}$ following the modifications proposed by Rufino et al. ${ }^{17}$

The vitamin $\mathrm{C}$ content was determined by spectrophotometry at $520 \mathrm{~nm}$ and expressed in $\mathrm{mg}$ per 100 $\mathrm{g}$ of acerola pulp, according to the procedure described by Oliveira. ${ }^{18}$ The total carotenoid content was determined by spectrophotometry at $520 \mathrm{~nm}$ according to RodriguezAmaya and Kimura, ${ }^{19}$ the results being expressed in $\mu \mathrm{g}$ of carotenoids per $1 \mathrm{~g}$ of acerola pulp. All analyses were performed in triplicate.

\subsection{Determination of antioxidant activity by ABTS and DPPH methods}

The total antioxidant activity was determined by scavenging the $\mathrm{ABTS}^{+}$radical, according to the methodology proposed by Re et al. ${ }^{20}$ The decrease in absorbance was measured after 6 minutes of the reaction and the reading was performed at $734 \mathrm{~nm}$. The results were expressed as $\mu \mathrm{mol}$ of Trolox per $1 \mathrm{~g}$ of fruit, from the standard Trolox curve.

The determination of antioxidant activity was also measured as a function of DPPH radical scavenging activity from the method described by Brand-Williams et al., ${ }^{21}$ with modifications proposed by Rufino et al. ${ }^{17}$ The decrease in absorbance was measured at $515 \mathrm{~nm}$ after 15 minutes of reaction. The antioxidant activity was expressed as $\mathrm{EC}_{50}$ (amount of antioxidant needed to reduce the initial DPPH concentration by $50 \%$ ).

\subsection{Statistical analysis}

The data of the physicochemical characteristics were submitted to the analysis of variance (ANOVA) and means were compared by the Tukey test at $5 \%$ probability level using the SISVAR 5.3 program. Principal component analysis (PCA) was also performed, from the correlation matrix, and the Pearson's correlation coefficients (r) 
between bioactive compounds and antioxidant activity were calculated using the Statistica 7.0 program.

\section{Results and Discussion}

Among the characteristics evaluated, there was a significant difference $(\mathrm{p}<0.05)$ for the color parameters $\mathrm{C} *$ and $\mathrm{h} *$, titratable acidity, $\mathrm{EC}_{50}$ and total extractable polyphenols (Table 1). The $\mathrm{C}^{*}$ value represents the color saturation so that the higher the value, the more intense and purer the color. The $\mathrm{h}^{*}$ angle is used as an analytical tool because it is the attribute by which the color is perceived as red, yellow, green, or blue. ${ }^{22}$ The $\mathrm{h} *$ values range from 0 (pure red), 90 (pure yellow), 180 (pure green) to 270 (pure blue). The CMF07-60-07 genotype had the highest $\mathrm{C} *$ and $\mathrm{h} *$ values, which means that its fruits have a more intense orange color than those of the other genotypes.

The fruits of the Okinawa genotype had a lower value of color angle $\left(\mathrm{h}^{*}\right)$ than those of the CMF07-60-07 genotype, being closer to the value of pure red. Canuto et al. ${ }^{23}$ found $\mathrm{C}^{*}$ values for acerola pulp lower than those obtained in this study (33.2), indicating less intense color of the evaluated genotypes.

The CMF07OKSE-3 and Okinawa genotypes showed lower $\mathrm{EC}_{50}$ values (Table 1), therefore, greater antioxidant activities since this relationship is inverse, that is, the lower the $\mathrm{EC}_{50}$ value, the greater the antioxidant activity. The CMFOKSE-3 genotype stood out for having a higher TEP content than CMF07-60-07.

The data presented in Table 1 are close to the results obtained in several studies. Godoy et al. ${ }^{24}$ evaluated fruits from different acerola genotypes and observed $\mathrm{pH}$ values between
3.29 and 3.60 and ratio between 5.84 and 10.31. Santos et al. ${ }^{7}$ characterized acerola fruits and obtained $\mathrm{pH}$ values between 3.41 and 3.52, acidity between $0.86 \%$ and $0.94 \%$ of malic acid, soluble solids between 4.7 and $5.3^{\circ} \mathrm{Brix}$ and ratio between 5.33 and 5.74. França and Narain $^{25}$ evaluated three varieties of acerola and found an average moisture content of 91.97 to $92.88 \%$, ash contents between 0.33 and $0.37 \%$ and total sugars between 4.19 and $4.61 \%$. Analyses of fruits from the variety Okinawa harvested in two seasons in Adamantina, SP, were carried out by NASSER et al. ${ }^{26}$ who found similar results to those of this work, with mean values of 3.18 for $\mathrm{pH}, 7.53$ ${ }^{\circ}$ Brix for soluble solids, $1,802.75 \mathrm{mg} / 100 \mathrm{~g}$ of ascorbic acid and $1.35 \%$ of citric acid for acidity.

The average values of vitamin $\mathrm{C}$ obtained in this study (Table 1) were higher than those reported by Neto et al. ${ }^{27}$ who found levels of vitamin $C$ between 744.5 and 1,434.8 $\mathrm{mg} 100 \mathrm{~g}^{-1}$ when evaluating fruits of 25 acerola clones. The vitamin $C$ content and other characteristics attributed to the quality of acerola, such as yield, fruit size, acidity, soluble solids content, color and $\mathrm{pH}$, are affected by the genotype, rainfall, temperature, insolation, altitude, fertilization, irrigation, occurrence of pests and diseases, harvesting season and the stage of ripeness. ${ }^{11,26,28,29,30}$

In the research conducted by Rufino et al. ${ }^{17}$ with acerola, $\mathrm{EC}_{50}$ values equal to $670 \pm 64.5 \mathrm{~g} \mathrm{~g}^{-1}$ of DPPH were found, which represents greater antioxidant activity compared to the data of the present study $\left(\mathrm{EC}_{50}\right.$ ranging from $3,276.67$ to $\left.7,738.03 \mathrm{~g} \mathrm{~g}^{-1} \mathrm{DPPH}\right)$. The same authors also found greater antioxidant activity $\left(96.6 \pm 6.1 \mu \mathrm{mol}\right.$ Trolox $\left.\mathrm{g}^{-1}\right)$ using the $\mathrm{ABTS}^{+}$radical scavenging method. In another research study carried out by SERAGLIO et al. ${ }^{31}$ with other acerola genotypes, DPPH values ranging from 963.23 to $1,120.40$ $\mathrm{mg}$ Trolox $\mathrm{g}^{-1}$ in the dry matter were obtained.

Table 1. Mean values of physical and physicochemical evaluations of the fruits of three acerola genotypes harvested in 2014

\begin{tabular}{|c|c|c|c|c|c|}
\hline Genotypes & CMF07-60-07 & CMF07OKSE-3 & OKINAWA & Mean & $p$ value \\
\hline $\mathrm{L}^{*}$ & 37.71 & 35.52 & 34.48 & 35.90 & 0.53 \\
\hline $\mathrm{C}^{*}$ & $55.84 \mathrm{a}$ & $49.08 b$ & $43.43 b$ & - & 0.00 \\
\hline $\mathrm{h}^{*}$ & $30.08 \mathrm{a}$ & $26.23 \mathrm{ab}$ & $21.31 b$ & - & 0.00 \\
\hline $\mathrm{pH}$ & 3.19 & 3.21 & 3.1 & 3.16 & 0.37 \\
\hline Soluble solids ( ${ }^{\circ}$ Brix $)$ & 7.95 & 8.95 & 7.36 & 8.08 & 0.66 \\
\hline Titratable acidity ( $\%$ malic acid) & $1.30 \mathrm{~b}$ & $1.56 \mathrm{ab}$ & $1.70 \mathrm{a}$ & - & 0.01 \\
\hline Ratio & 6.06 & 5.70 & 4.30 & 5.35 & 0.24 \\
\hline Moisture (\%) & 91.86 & 93.86 & 92.79 & 92.83 & 0.79 \\
\hline Ashes $(\%)$ & 0.38 & 0.42 & 0.33 & 0.37 & 0.32 \\
\hline Total sugars (\% glucose) & 4.46 & 4.97 & 3.56 & 4.33 & 0.60 \\
\hline Total carotenoids $\left(\mu \mathrm{g} 100 \mathrm{~g}^{-1}\right)$ & $15.88 \mathrm{a}$ & $4.58 \mathrm{a}$ & 7.02a & 9.16 & 0.11 \\
\hline Vitamin C (mg $\left.100 \mathrm{~g}^{-1}\right)$ & $1,282.07 \mathrm{a}$ & $1,929.36 \mathrm{a}$ & $1,935.21 \mathrm{a}$ & 1715.54 & 0.04 \\
\hline $\mathrm{EC}_{50}\left(\mathrm{~g} \mathrm{~g}^{-1} \mathrm{DPPH}\right)$ & $7,738.18 \mathrm{a}$ & $3,276.67 b$ & $3,477.45 b$ & - & 0.02 \\
\hline TEP (mg gallic acid $\mathrm{g}^{-1}$ ) & $410.82 b$ & $764.22 \mathrm{a}$ & $673.29 \mathrm{ab}$ & - & 0.03 \\
\hline AA ABTS $\left(\mu \mathrm{M}\right.$ Trolox $\left.\mathrm{g}^{-1}\right)$ & 2.72 & 5.84 & 4.09 & 4.22 & 0.18 \\
\hline
\end{tabular}

L*: lightness; $\mathrm{C}^{*}$ : color intensity; $\mathrm{h}^{*}$ : angle of color / hue; EC50: efficient concentration; TEP: total extractable polyphenols; ABTS: antioxidant activity by scavenging the ABTS+ radical; means followed by equal letters do not differ by the Tukey test at $5 \%$ probability level; n.s: not significant 
The results of the principal component analysis (PCA), considering all the characteristics evaluated, are represented in Figure 1. The first two principal components (PC) explained $100 \%$ of the data variation (Figure 1A). Therefore, the diversity of the genotypes can be represented based on these two PCs. All the characteristics evaluated showed significant correlations $(\mathrm{p}<0.05)$, with at least one principal component, so it is important to discriminate the different acerola genotypes (Figure 2B).

Although the Tukey test did not show any significant difference between the carotenoid levels of the three genotypes studied (Table 1), the principal component analysis (PCA) showed that CMF07-60-03 genotype, located in the first quadrant, showed a higher total carotenoid content and higher values for the parameters $\mathrm{L}^{*}, \mathrm{C}^{*}$ and $\mathrm{h}^{*}$ (Figures 1A and 1B). The high value of $\mathrm{C}^{*}$ indicates that the color of this genotype is more intense than in the others and that, in this case, it is directly associated with the higher content of total carotenoids of this genotype, which also had a higher $\mathrm{EC}_{50}$ (Figure 1B), and therefore, lower antioxidant activity by the DPPH method than the other evaluated genotypes. This variety also stood out for having a higher ratio according to the PCA, which means that it has the potential to be well accepted sensorially, as the ratio is a quality index related to the perception of fruit sweetness by consumers. Silva et al. ${ }^{32}$ also got a high content of carotenoids in acerola in their research, ranging from 23.49 to $32.30 \mathrm{mg} 100 \mathrm{~mL}^{-1}$ in the form of $\beta$-carotene.

The Okinawa variety, located in the second quadrant, had the lowest values for the color parameters $\mathrm{L}^{*}, \mathrm{C}^{*}$ and $\mathrm{h}^{*}$, in addition to the lowest ratio, that is, less sweetness (Figures $1 \mathrm{~A}$ and $1 \mathrm{~B}$ ).

The CMF07-OKSE-3 hybrid, located in the third quadrant (Figure 1A), showed higher levels of moisture, vitamin $\mathrm{C}$, total polyphenols, and greater antioxidant activity by the ABTS method. However, by univariate analysis (Table 1), antioxidant activity and moisture and vitamin C levels did not differ significantly.

There was no significant correlation $(p>0.05)$ between the carotenoid content and the other variables evaluated (Table 2). The fact that there was no significant correlation between antioxidant activity and carotenoid levels does not mean that these compounds do not contribute to this activity. This result may be due to the methods of analysis used or to mechanisms of synergism and antagonism between such compounds that are still unknown. In the research carried out by Santos et $\mathrm{al}^{33}$ and Reis et al. ${ }^{34}$, there were also no correlations between carotenoid content and antioxidant activity in cupuaçu and papaya pulps, respectively.

Significant positive correlations were obtained between vitamin $\mathrm{C}$ and TEP content (Table 2), indicating that fruits with higher levels of vitamin $\mathrm{C}$ also had higher levels of TEP.
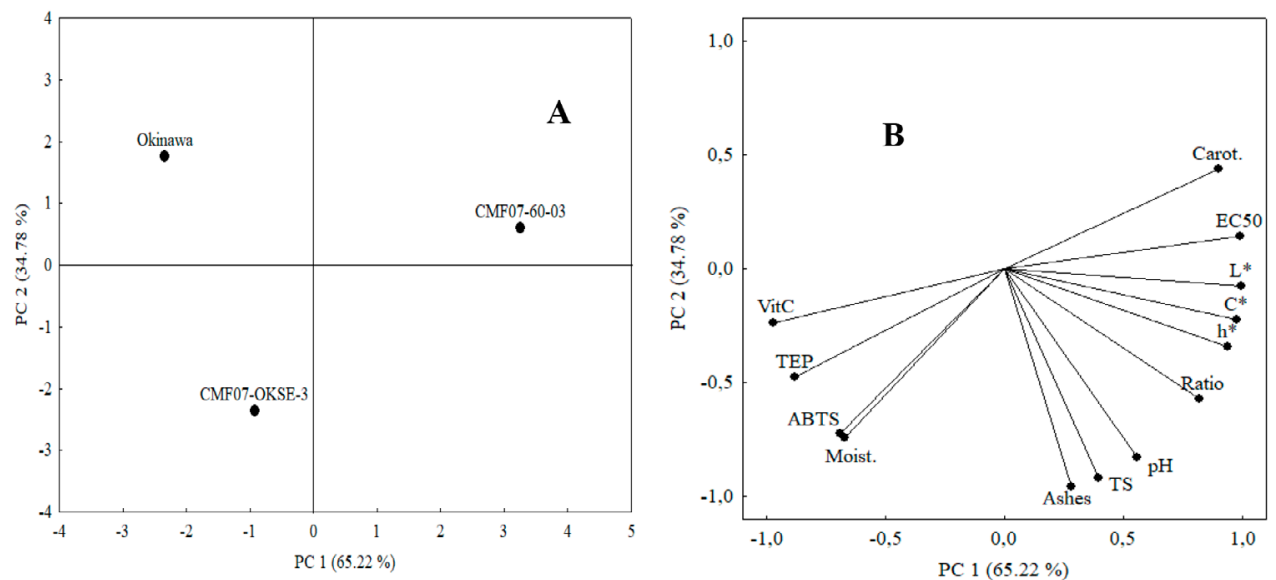

Figure 1. A- Dispersion of acerola genotypes by principal component analysis. B- Correlations among the physicochemical characteristics and the two principal components. $\mathrm{C}^{*}$ : color intensity; $\mathrm{L}^{*}$ : lightness; $\mathrm{h}^{*}$ : color angle/hue; TEP: total extractable polyphenols; Moist.: moisture; Vit C: vitamin C; TS: total sugars; EC50: efficient concentration; Carot.: total carotenoids

Table 2. Pearson's Correlation Coefficients (r) between bioactive compounds and antioxidant activity

\begin{tabular}{lcccc}
\hline PPCC $(\mathbf{r})$ & Vit $\mathbf{C}$ & $\mathbf{E C}_{\mathbf{5 0}}$ & TEP & ABTS \\
\hline Carot & -0.62 & 0.61 & -0.53 & -0.52 \\
Vit C & & -0.57 & $0.81^{*}$ & 0.71 \\
EC $_{50}$ & & & $-0.82^{* *}$ & -0.54 \\
TEP & & & & $0.87 * *$ \\
\hline
\end{tabular}

PPCC - Pearson's Partial Correlation Coefficient, * significant at $\mathrm{p}<0.05$;

** significant at $\mathrm{p}<0.01 ;$ TEP- total extractable polyphenols; Vit C: vitamin

$\mathrm{C} ; \mathrm{EC}_{50}$ : efficient concentration; Carot: total carotenoids 
It is also observed that, among the evaluated compounds, phenolics are the ones that most contributed to the antioxidant activity of the acerola pulp, a fact that can be observed by the significant correlations between TEP, $\mathrm{EC}_{50}$ and ABTS (Table 2). Rufino et al. ${ }^{17}$ also found a significant correlation between vitamin $\mathrm{C}$ and TEP $(\mathrm{r}=0.70)$ and between TEP content and antioxidant activity determined by the ABTS $(r=0.92)$ and $\operatorname{DPPH}(\mathrm{r}=-0.72)$ methods, when evaluating 18 tropical fruits, including acerola. Almeida et al..$^{35}$ and Rodrigues et al. ${ }^{36}$ found significant correlations ( $\mathrm{p}<0.05$ ) between TEP content and antioxidant activities by ABTS and DPPH methods when evaluating exotic and blueberry fruits, respectively. However, Reis et al. ${ }^{34}$ found significant correlations only between TEP content and antioxidant activity using the DPPH method in papaya genotypes. It is worth mentioning that these results are dependent on the methods of analysis used.

\section{Conclusions}

Principal components analysis made it possible to differentiate the genotypes of acerola, with emphasis on the hybrid CMF07-OKSE-3, which showed greater antioxidant activity, higher levels of vitamin $\mathrm{C}$ and total extractable polyphenols, in addition to a higher ratio, with the potential to be well accepted by the consumer market.

\section{References}

1. Nakasone, H. Y.; Paull, R. E.; Em Tropical fruits, Nakasone, H. Y.; Paull, R. E., CABI: Wallingford 1998, cap 14.

2. Santos, J.A. N.; Santos, M.A.; Evangelista, F. R.; Alves, M. O.; Pires, I. J. B.; Fruticultura nordestina: desenvolvimento recente e possibilidade de políticas. Fortaleza: Banco do Nordeste do Brasil, 2007.

3. Olisson, M. E.; Andersson, C. S.; Berglund, R. H.; Gustavsson, K. E.; Antioxidant levels and inhibition of cancer cell proliferation in vitro by extracts from organically and conventionally cultivated strawberries. Journal of Agricultural and Food Chemistry 2006, 54, 1248. [CrossRef] [PubMed]

4. Neto, J. C.; Rabelo, M. C.; Bertini, C. H. C. M; Marques, G. V.; Miranda, M. R. A.; Caracterização agronômica e potencial antioxidante de frutos de clones de aceroleira. Revista Ciência Agronômica 2012, 43, 713. [Link]

5. Laguerre, M.; Lecomte, J.; Villeneuve, P.; Evaluation of the ability of antioxidants to counteract lipid oxidation: existing methods, new trends and challenges. Review. Progress in Lipid Research 2007, 46, 244. [CrossRef][PubMed]

6. Silva, M. L. C.; Costa, R. S.; Santana, A. S.; Koblitz, M. G. B.; Compostos fenólicos, carotenóides e atividade antioxidante em produtos vegetais. Semina: Ciências Agrárias 2010, 31, 669. [Link]

7. Santos, S. M. L.; Vasconcelos, A. M.; Oliveira, V. S.; Clemente, E.; Costa, J. M. C.; Evaluation of physical and physicochemical characteristics of Malpighia emarginata DC from the state of Ceará. International Journal of Biochemistry Research \& Review 2012, 2,152. [Link]
8. Mercali, G. M.; Jaeschke, D. P.; Tessaro, I. C.; Marczak, L. D. F.; Degradation kinetics of anthocyanins in acerola pulp: comparison between ohmic and conventional heat treatment. Food Chemistry 2013, 136. [CrossRef] [PubMed]

9. Ministério da Saúde. Visalegis: Legislação em Vigilância Sanitária. Resolução da Diretoria Colegiada - RDC n. 269, de 22 de setembro de 2005. Regulamento Técnico sobre a Ingestão Diária Recomendada (IDR) de Proteína, Vitaminas e Minerais. Available at: http://www.in.gov.br/materia/-/asset_publisher/ Kujrw0TZC2Mb/content/id/34379969/do1-2018-07-27resolucao-da-diretoria-colegiada-rdc-n-243-de-26-de-julhode-2018-34379917. Accessed on: January 30th 2020.

10. De Rosso, V. V.; Mercadante, A. Z.; Carotenoid composition of two brazilian genotypes of acerola (Malpighia punicifolia L.) from two harvests. Food Research Internacional 2005, 8, 1073. [CrossRef]

11. Lima, V. L. A. G.; Melo, E. A.; Maciel, M. I. S.; Prazeres, F. G.; Musser, R. S.; Lima, D. E. S.; Total phenolic and carotenoid contents in acerola genotypes harvested at three ripening stages. Food Chemistry 2005, 90, 565. [CrossRef]

12. Silva, T. S. M.; Coelho-Filho, M. A.; Coelho, E. F.; Boletim meteorológico da estação convencional de Cruz das Almas, BA: variabilidade e tendências climáticas. Cruz das Almas : Embrapa Mandioca e Fruticultura, 2016. 72p. Available at: <https://ainfo. cnptia.embrapa.br/digital/bitstream/item/145992/1/Documentos-216Boletim-Meteorologico.pdf>. Accessed in: September 25th 2018.

13. Instituto Adolfo Lutz; Métodos físico-químicos para análise de alimentos. 4 th edition. Ministério da Saúde: Brasília-DF: 2008.

14. Nelson, N.; A photometric adaptation of the Somogy method for the determination of glucose. Journal of Biological Chemistry, 1944, 53, 375. [Link]

15. Larrauri, J. A.; Rupérez, P.; Saura-Calixto, F.; Effect of drying temperature on the stability of polyphenols and antioxidant activity of red grape pomace peels. Journal of Agriculture and Food Chemistry 1997, 45, 1390. [CrossRef]

16. Singleton, V. L.; Orthofer, R.; Lamuela-Raventós, R. M.; Analysis of total phenols and other oxidation substrates and antioxidants by means of Folin-Ciocalteu reagent. Methods in Enzymology 1999, 299, 52. [CrossRef]

17. Rufino, M. S. M.; Alves, R. E.; Brito, E. S.; Pérez-Jiménez, J.; Saura-Calixto, F.; Mancini-Filho, J.; Bioactive compounds and antioxidant capacities of 18 non-traditional tropical fruits from Brazil. Food Chemistry 2010, 121, 996. [CrossRef]

18. Oliveira, L. A.; Manual de Laboratório: Análises físico-químicas de frutas e mandioca. Embrapa Mandioca e Fruticultura: Cruz das Almas, 2010.

19. Rodriguez-Amaya, D.; Kimura, M.; Harvest Plus Handbook for Carotenoid Analysis. IFPRI and CIAT: Washington, 2004.

20. Re, R.; Pellegrini, N., Proteggene, A., Pannala, A., Yang, M, Rice-Evans, C.; Antioxidant activity applying improved ABTS radical cation decolorization assay. Free Radical Biology and Medicine 1999, 26, 1231. [CrossRef] [PubMed]

21. Brand-Williams, W.; Cuvelier, M. E.; Berset, C.; Use of a free radical method to evaluate antioxidant activity. Food Science and Technology 1995, 28, 25. [CrossRef]

22. Ramallo, L. A.; Mascheroni, R. H.; Quality evaluation of pineapple fruit during drying process. Food and Bioproducts Processing 2012, 90, 275. [CrossRef] 
23. Canuto, G. A. B.; Xavier, A. A. O.; Neves, L. C.; Benassi, M. T.; Caracterização físico-química de polpas de frutos da Amazônia e sua correlação com a atividade anti-radical livre. Revista Brasileira de Fruticultura 2010, 32, 1196. [CrossRef]

24. Godoy, R. C. B.; Matos, E. L. S.; Amorim, T. S.; Neto, M. A. S.; Ritzinger, R.; Waszczynskyj, N.; Avaliação de genótipos de variedades de acerola para consumo in natura e para elaboração de doces. Boletim do Centro de Pesquisa e Processamento de Alimentos 2008, 26, 197.

25. França, V. C.; Narain, N.; Caracterização química dos frutos de três matrizes de acerola (Malpighia emarginata D.C.). Ciência e Tecnologia de Alimentos 2003, 23, 57. [CrossRef]

26. Nasser, M. D.; Mariano-Nasser, F. A. C.; Furlaneto, K. A.; Ramos, J. A.; Caetano, P. K.; Composição da acerola de diferentes genótipos em duas épocas de colheita. Nativa 2018, 6, 15. [CrossRef]

27. Neto, J. C.; Rabelo, M. C.; Bertini, C. H. C. M.; Marques, G. V.; Miranda, M. R. A.; Agronomic characterization and antioxidant potential of fruit from clones of the acerola plant. Revista Ciência Agronômica 2012, 43, 713. [CrossRef]

28. Mezadri, T. D.; Villaño, D.; Fernández-Pachón, M. S.; GarcíaParrilla, M. C.; Troncoso, A. M.; Antioxidant compounds and antioxidant activity in acerola (Malpighia emarginata DC.) fruits and derivatives. Journal of Food Composition and Analysis 2008, 21, 282. [CrossRef]

29. Estevam, M. I. F.; Souza, P. A.; Maracajá, P. B.; Batista, E. M.; Reges, B. M.; Físico-química de variedades de acerola em dois estádios de maturação. Revista Verde de Agroecologia e Desenvolvimento Sustentável 2018, 13, 459. [CrossRef]
30. Souza, J. F.; Santana, E. A.; Silva, A. S. S.; Souza, A. C. F. S.; Avaliação físico-química de acerola, Malpighia emarginata DC., proveniente de Macapá-Amapá. Journal of Biology \& Pharmacy and Agricultural Management 2020, 16, 156. [CrossRef]

31. Seraglio, S. K. T.; Mayara, S.; Nehring, P.; Betta, F. D.; Valese, A. C.; Daguer, H.; Gonzagas, L. V.; Fett, R.; Costa, A. C. O.; Determinação de compostos fenólicos por LC-MS/MS e capacidade antioxidante de acerola em três estádios de maturação comestíveis. Revista CSBEA 2018, 4, 96. [CrossRef]

32. Silva, M. L. S.; Menezes, C. C.; Portela, J. V. F.; Alencar, P. E. B. S.; Carneiro, T. B.; Teor de carotenoides em polpas de acerola. Revista Verde de Agroecologia e Desenvolvimento Sustentável 2013, 8, 170. [CrossRef]

33. Santos, G. M.; Maia, G. A.; Machado, P. H. S.; Figueiredo, R. W.; Costa, J. M. C.; Fonseca, A. V. V.; Atividade antioxidante e correlações com componentes bioativos de produtos comerciais de cupuaçu. Ciência Rural 2010, 40, 1636. [CrossRef]

34. Reis, R. C.; Viana, E. S.; Jesus, J. L.; Lima, L. F.; Neves, T. T.; Conceição, T. T.; Compostos bioativos e atividade antioxidante de variedades melhoradas de mamão. Ciência Rural 2015, 45, 2076. [CrossRef]

35. Almeida, M. M. B.; Sousa, P. H. M.; Arriaga, A. M. C.; Prado, G. M.; Magalhães, C.E. C.; Maia, G.A.; Lemos, T.L. G.; Bioactive compounds and antioxidant activity of fresh exotic fruits from northeastern Brazil. Food Research International 2011, 44, 2155. [CrossRef]

36. Rodrigues, E.; Poerner, N.; Rockenbach, I. I.; Gonzaga, L. V.; Mendes, C. R.; Fett, R.; Phenolic compounds and antioxidant activity of blueberry cultivars grown in Brazil. Ciência e Tecnologia de Alimentos 2011, 31, 911. [Link] 